\title{
UPAYA MENINGKATKAN HASIL BELAJAR SISWA PADA MATERI IPA DENGAN MENGGUNAKAN MODEL SNOWBALL THROWING DI KELAS IV SD NEGERI 050604 BEKIUN
}

\author{
Rita Herlina Br PA*1, Ester Novitalina Br Tarigan ${ }^{* 2}$ \\ Dosen FKIP Universitas Quality ${ }^{* 1}$, Guru SD Negeri 050604 Bekiun $^{* 2}$ \\ Email :rperanginangin@gmail.com ${ }^{* 1}$, esternovitalinatarigan@ gmail.com ${ }^{* 2}$
}

\begin{abstract}
ABSTRAK
Penelitian dilaksanakan karena terdapat masalah terhadap hasil belajar siswa. Masalah yang dihadapi siswa yaitu kurang maksimal menggunakan alat atau media pembelajaran, sehingga siswa kurang memiliki semangat belajar dan kurang tertarik dan kurang aktif dalam mengikuti pelajaran IPA di dalam kelas..Untuk mengatasi permasalahan tersebut, maka dilakukan penelitian menggunakan model Snowball Throwing yang bertujuan untuk mengetahui pelaksanaan pembelajaran dan meningkatkan hasil belajar IPA siswa.Jenis penelitian adalah Penelitian Tindakan Kelas. Alat pengumpul data yang digunakan pada saat penelitian adalah lembar observasi dan tes yang telah divalidasi oleh validator. Penelitian dilaksanakan sebanyak 2 siklus dan setiap siklus dilaksanakan selama 2 jam pelajaran. Berdasarkan hasil penelitian diperoleh hasil observasi guru dan siswa yang kategori baik. Rata-rata hasil belajar siswa pada siklus I dan II yaitu 69,27dan72,5. Pada siklus I terdapat $20(74,10 \%)$ siswa tuntas KKM sedangkan pada siklus II terdapat $24(88,90 \%)$ siswa tuntas KKM. Ketuntasan hasil belajar siswa telah mencapai tuntas secara klasikal.Berdasarkan hasil penelitian maka dapat dinyatakan bahwa penggunaan model Snowball Throwing dapat meningkatkan hasil belajar siswa pada pelajaran IPA materi sumber daya alam dan hasilnya di kelas IV SD Negeri 050604 Bekiun tahun pelajaran 2016/2017.
\end{abstract}

\section{Kata Kunci: Hasil Belajar, Model Snowball Throwing}

The study was conducted because there were problems with the students' learning outcomes. Problems faced by students that is less than the maximum use of tools or learning media, so that students lack the spirit of learning and less interested and less active in following the science lesson in the class. To overcome these problems, then conducted research using Snowball Throwing model which aims to know the implementation Learning and improve students' learning outcomes. The type of research is Classroom Action Research. Data collection tools used at the time of the study are observation sheets and tests validated by validators. The study was conducted in 2 cycles and each cycle was held for 2 hours. Based on the research results obtained the observation of teachers and students who expressed good category. The average of student learning outcomes in cycle I and II is 69,27 and 72,5 . In cycle I, there are $20(74,10 \%)$ students complete KKM whereas in cycle II there are $24(88,90 \%)$ students complete KKM. Completeness of student learning outcomes has been completed in a classical way. Based on the results of the research it can be stated that the use of Snowball Throwing model can improve student learning outcomes in science lessons of natural resources materials and the results in class IV SD Negeri 050604 Bekiun year 2016/2017 lessons. 


\section{Keywords: Learning Outcomes, Snowball Throwing Model}

\section{Pendahuluan}

Pendidikan adalah usaha yang disengaja dan terencana untuk membantu meningkatkan prestasi dan kemampuan siswa agar bermanfaat bagi kepentingan hidup. Sumber daya yang berkualitas akan menentukan mutu kehidupan pribadi, masyarakan dan bangsa dalam rangka mengatasi persoalan-persoalan dan tantangantantangan yang terjadi pada masa kini dan masa depan.

Oemar Hamalik (2016:79) berpendapat bahwa "Pendidikan adalah suatu proses dalam rangka mempengaruhi siswa agar dapat menyesuaikan diri sebaik mungkin terhadap lingkungannya dan dengan demikian akan menimbulkan perubahan dalam dirinya yang memungkinka nya untuk berfungsi secara edukasi dalam kehidupan masyarakat".

Dalam undang - undang Republik Indonesia No. 20 Tahun 2003 tentang Sisem Pendidikan Indonesia yang dapat diketahui "Tujuan Pendidikan nasional adalah mencerdaskan kehidupan bangsa, membentuk manusia Indonesia seutuhnya yaitu manusia yang bertaqwa kepada Tuhan Yang MahaEsa, berbudiluhur, memiliki pengetahuan dan keterampilan, sehatj asmani dan rohani, mempunyai kepribadian dan mandiri serta mempunyai rasa tanggung jawab kemasyarakatan dan kebangsaan".

Guru memegang peran penting untuk pencapaian misipembaharuan pendidikan mengatur dan mengarahkan dan menciptakan suasana kegiatan belajar mengajar untuk mencapai tujuan dan misi pendidikan nasional. Guru dituntut untuk kreatif dalam mengelola pembelajaran dengan menciptakan suasana belajar yang berfariasi melalui berbagai metode dan model pembelajaran. Guru juga dituntut untuk mampu menggunakan alat peraga dan media dengan maksimal agar dapat memudahkan siswa untuk memahami pembelajaran dengan lebih nyatasehingga dapat meningkatkan minat siswa dalam mengikuti pembelajaran dan dapat meningkatkan hasil belajar siswa.

Pada dasarnya pembelajaran yang dilakukan di kelas diharapkan dapat menjadi proses perubahan pada siswa. Siswa diharapkan memiliki semangat belajar yang tinggi sehingga siswa berperan aktif dalam proses pembelajaran. Siswa diharapkan mampu memahami pembelajaran yang diberikan oleh guru dan mencapai indikator serta tujuan pembelajaran yang sudah di rencanakan guru dan mendapatkan nilai yang mencapai kriteria ketuntasan minimum.

Perubahan yang diharapkan tersebut dapat terlaksana dengan berbagai upaya yang dapat dilakukan oleh individu maupun kelompok diantaranya yaitu melaui pendidikan yang didapat dari keluarga, sekolah maupun masyarakat. Perubahan yang didapat baik dari pengalaman atau pun pendidikan tersebut akan membentuk kepribadian dan karakter seorang manusia yang seutuhnya. Menurut informasi yang diperoleh dari guru (wali kelas) IV SD Negeri 050604 Bekiun bahwa hasil belajar siswa pada mata pelajaran Ilmu Pengetahuan Alam kurang maksimal atau belum memuaskan. Rendahnya pengetahuan siswa pada mata pelajaran Ilmu Pengetahuan Alam berpengaruh terhadap hasil belajarnya.

Informasi dari Kepala Sekolah bahwa dalam proses pembelajaran guru cenderung menggunakan metode ceramah, guru kurang maksimal menggunakan alat atau media pembelajaran, sehingga siswa kurang memiliki semangat belajar dan kurang tertarik dan kurang aktif dalam mengikuti pelajaran di dalam kelas.

Masalah tersebut semakin jelas dari informasi guru mengenai hasil belajar siswa pada ulangan lmu Pengetahuan Alam seperti Tabel 1 
Tabel 1 Nilai hasil ulangan semester pada pelajaran IPA kelas IV

\begin{tabular}{|c|c|c|c|c|}
\hline \multirow{2}{*}{ No } & \multirow{2}{*}{ KKM } & Nilai & $\begin{array}{c}\text { Jumlah } \\
\text { Siswa }\end{array}$ & Persentase \% \\
\hline 1 & \multirow{2}{*}{65} & $\geq 65$ & 11 & $52.38 \%$ \\
\hline 2 & $<65$ & 10 & $47,61 \%$ \\
\hline \multicolumn{2}{|r|}{ Jumlah } & 21 & $100 \%$ \\
\hline
\end{tabular}

Sumber:Daftar nilai hasil ulangan semester pada mata pelajaran IPA di kelas IV SD 050604 BEKIUN Tahun Ajaran 2016/2017.

Berdasarkan Tabel 1 terlihat bahwa dari 21 orang siswa hanya $11(52,38 \%)$ orang siswa yang nilainya diatas Kriteria Ketuntasan Minimal dan $10(47,61 \%)$ orang siswa yang nilainya di bawah Kriteria Ketuntasan Minimal.

Guru memberikan penjelasan lebih merinci bahwa dari 21 jumlah peserta didik di dalam satu kelas hanya 5 siswa saja yang memiliki semangat belajar yang tinggi saat belajar IPA dan dapat menyelesaikan tugas mendapatkan nilai yang cukup baik, 6siswa lainnya mampu menyelesaikan tes setelah diberikan latihan individu dan 10 siswa lainnya kurang peduli terhadap pelajaran karena merasa sulit untuk memahami pelajaran IPA tersebut.

Masalah yang terjadi seperti yang dijelaskan oleh guru kepada peneliti sebenarnya berkaitan dengan berbagai faktor. Faktor dari guru yang mengakibatkan masalah tersebut terjadi adalah karena (1) Guru belum melaksanakan pembelajaran dengan maksaimal kerena model pembelajaran yang digunakan guru pada pembelajaran kurang berfariasi, (2) Guru belum menggunakan alat peraga dan media secara maksimal dan guru kurang mengembangkan bahan pembelajaran yang nyata dalam kehidupan sehari-hari.

Faktor dari siswa yang mengakibatkan terjadi masalah adalah kerana (1) siswa tidak merasa termotivasi untuk belajar ; sehingga siswa susah memahami materi yang diajarkan guru, (2) siswa tidak terlibat aktif dalam kegiatan pembelajaran.

Pelaksanaan proses belajar mengajar di sekolah senantiasa diharapkan berlangsung dengan baik. Sehingga tercapai tujuan pembelajaran yang ingin dicapai. Dengan demikian dapat mencapai peningkatan hasil belajar siswa yang baik, dengan ada nya tanggung jawab guru yang terlibat dalam proses pembelajaran tersebut untuk memperoleh keberhasilan dengan menggunakan model dan mengusahakan media pembelajarandalam proses belajar mengajar sesuai dengan matapelajaran.

Perlunya penggunaan model pembelajaran yang bervariasi diharapkan akan meningkatkan kualitas pembelajaran. Banyak model pembelajaran yang dapat digunakan dalam proses suatu pembelajaran.Model pembelajaran Snowball Throwing merupakan salah satu model yang tepat pada pelajaran IPA karena model pembelajaran Snowball Throwing dapat menciptakan suasana pembelajaran yang aktif dan dapat menarik perhatian siswa sehingga siswa dapat menerima pelajaran dan mengerti pelajaran tersebut, sehingga dapat meningkatkan hasil belajar yang maksimal.

Dari latar belakang masalah tersebut, maka penulis mengajukan untuk melakukan penelitian tindakan kelas.Penelitian tindakan kelas ini dirumuskan dengan judul Upaya Meningkatkan Hasil Belajar Siswa Pada Mata Pelajaran IPADengan Menggunakan Model Snowball Throwing Di Kelas IV SD Negeri No.050604 Bekiun Tahun Ajaran 2016/2017.

\section{Metode Penelitian}

Penelitian yang dilaksanakan adalah Penelitian Tindakan Kelas yang tujuannya untuk meningkatkan mutu proses dan hasil pembelajaran di kelas. Melalui Penelitian Tindakan Kelas, kelemahan-kelemahan dan masalahmasalah yang terjadi pada proses pembelajaran dan hasil belajar akan lebih mudah untuk diidenttifikasi. Selain 
itu, melalui Penelitian Tindakan Kelas solusi dari masalah dan kelemahan akan lebih mudah untuk ditemukan. pada penelitian ini akan menggunakan model

\section{Hasil dan Pembahasan}

Hasil Observasi Aktivitas Guru Siklus

I

Tabel 2 Hasil Observasi untuk Aktivitas Guru Siklus I

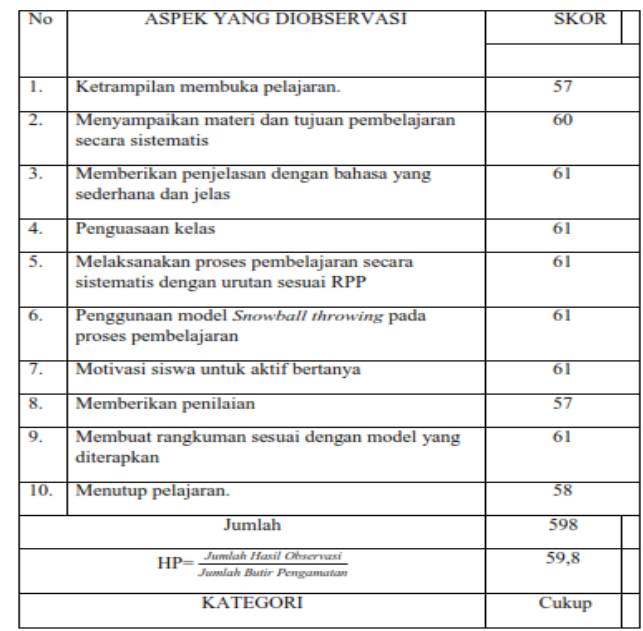

Berdasarkan tabel 2, maka diperoleh hasil pelaksanaan pembelajaran dari

aktivitas guru sebesar 59,8\% termasuk kategori cukup.
Suharsimi Arikunto (2014:16) dengan urutan kegiatan: 1) perencanaan, 2) pelaksanaan, 3) pengamatan, dan 4) refleksi.

Adapun hasil observasi ditunjukkan pada Tabel 2

\section{Hasil Observasi Aktivitas Siswa}

Adapun hasil observasi aktivitas siswa dapat dilihat pada Tabel 3

Tabel 3 Hasil Observasi untuk Aktivitas Siswa Siklus I

\begin{tabular}{|c|c|c|}
\hline No & ASPEK YANG DIOBSERVASI & PENILAIAN \\
\hline 1. & Kesiapan menerima pelajaran. & 4 \\
\hline 2. & Menerima penjelasan guru dengan baik & 4 \\
\hline 3. & Mendengarkan penjelasan guru & 4 \\
\hline 4. & Memperhatikan dan mencatat penjelasan guru & 4 \\
\hline 5. & Keaktifan menjawab pertanyaan guru & 4 \\
\hline 6. & Keaktifan bertanya & 3 \\
\hline 7. & Peningkatan aktifitas belajar & 2 \\
\hline 8. & Ketenangan kelas saat belajar & 3 \\
\hline 9. & Kesenangan belajar & 3 \\
\hline 10. & Ketertiban siswa pada saat belajar & 3 \\
\hline \multicolumn{2}{|r|}{ Jumlah } & 34 \\
\hline \multirow{2}{*}{\multicolumn{2}{|c|}{$\begin{array}{c}\text { Nilai Siswa }=\underline{\text { Skorperolehan }} \times 100 \\
\text { SkorMaksimal } \\
\text { KATEGORI }\end{array}$}} & 68 \\
\hline & & Cukup \\
\hline
\end{tabular}

hasil pelaksanaan pembelajaran dari aktivitas siswa diperoleh hasil sebesar 68 termasuk kategori cukup. 


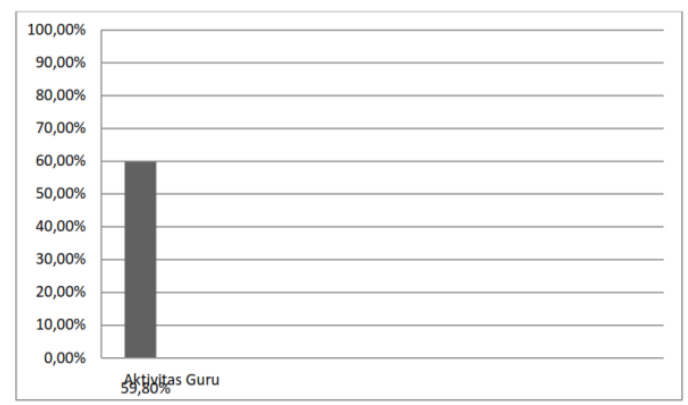

Gambar 1 Diagram Hasil Pelaksanaan Pembelajaran Aktivitas Guru Siklus I

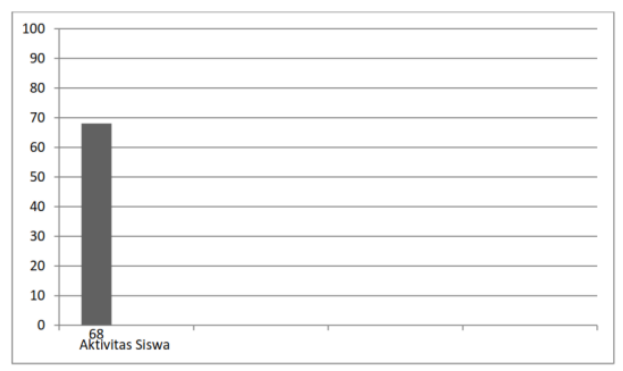

Gambar 2 Diagram Hasil Pelaksanaan Pembelajaran aktivitas siswa Siklus I

\section{Ketuntasan Hasil Belajar Siswa Siklus I}

\section{Ketuntasan Hasil Belajar Siswa}

\section{Secara Individu}

Berdasarkan hasil belajar yang diperoleh siswa pada pelaksanaan pembelajaran dengan model Snowball Throwing di
Kelas IV SD Negeri 050604 Bekiunmaka diperoleh data ketuntasan hasil belajar secara individu dapat dilihat pada Gambar 3

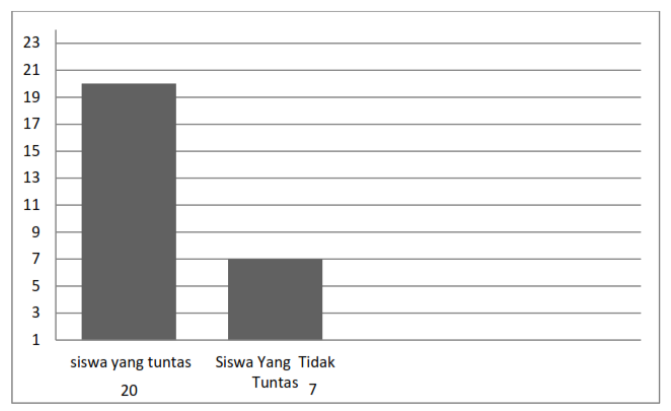

Gambar 3 Diagram Ketuntasan Hasil Belajar Siswa Secara Individu Siklus I

Ketuntasan Hasil Belajar Siswa Berdasarkan data ketuntasan hasil Secara Klasikal belajar siswa secara individu, maka dapat diperoleh ketuntasan belajar siswa secara klasikal seperti pada Tabel 4

Tabel 4 Ketuntasan Hasil Belajar Siswa Secara Klasikal Siklus I

\begin{tabular}{|c|c|c|c|}
\hline \multirow[t]{2}{*}{ Ketuntasan } & \multicolumn{2}{|c|}{ Siklus I } & \multirow[t]{2}{*}{ Keterangan } \\
\hline & Jumlah Siswa & Persentase & \\
\hline $\begin{array}{c}\text { Siswa yang tuntas } \\
\text { belajar }\end{array}$ & 20 & $74,1 \%$ & \multirow{3}{*}{$\begin{array}{l}\text { Ketuntasan } \\
\text { secara klasikal } \\
\text { belum tercapai }\end{array}$} \\
\hline $\begin{array}{l}\text { Siswa yang tidak tuntas } \\
\text { belajar }\end{array}$ & 7 & $25,9 \%$ & \\
\hline Jumlah & 28 & $100 \%$ & \\
\hline
\end{tabular}


Dari tabel 4, dapat dilihat bahwa siswa yang tuntas belajar pada siklus I sebesar $74,1 \%$ sedangkan siswa yang tidak tuntas sebesar 25,9\%. Hasil ini menunjukkan bahwa ketuntasan belajar siswa secara klasikal belum tercapai, karena suatu kelas dikatakan tuntas secara klasikal apabila dalam kelas tersebut $\geq 85 \%$ siswanya yang telah tuntas belajar atau tuntas individu. Hal ini juga dapat dilihat pada Gambar 4

\section{Gambar 4. Diagram Ketuntasan Hasil Belajar Siswa Secara Klasikal Siklus I}

\section{Rata-rata Hasil Belajar Siswa}

Data ketuntasan belajar siswa secara individu di atas dapat dirangkum dalam Tabel 5

Tabel 5 Distribusi Frekuensi Rata-rata hasil belajar siswa siklus I

\begin{tabular}{|c|c|c|c|c|}
\hline No. & Kelas Interval & $f i$ & $X i$ & Fixi \\
\hline 1. & $40-47$ & 1 & 43,5 & 43,5 \\
\hline 2. & $48-55$ & 2 & 51,5 & 103 \\
\hline 3. & $56-63$ & 4 & 59,5 & 238 \\
\hline 4. & $64-71$ & 8 & 67,5 & 540 \\
\hline 5. & $72-79$ & 7 & 75,5 & 528,5 \\
\hline 6. & $80-87$ & 5 & 83,5 & 417,5 \\
\hline \multicolumn{2}{|c|}{ Jumlah } & 27 & 381 & 1870,5 \\
\hline
\end{tabular}

Dari data nilai rata-rata siswa yang diperoleh pada Tabel 5 dapat disajikan melalui histogram pada Gambar 5

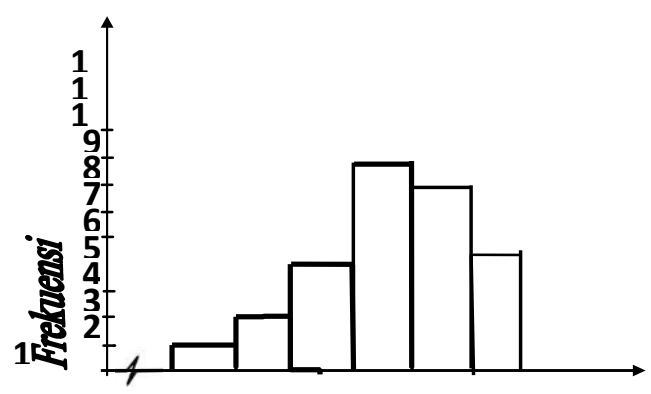

\section{Gambar 5 Histogram Data Hasil Belajar Siswa Siklus I}

\section{Refleksi Siklus I}

Dari hasil analisis data pada siklus I bahwa pelaksanaan pembelajaran dengan menggunakan model Snowball
Throwing pada mata pelajaran IPA materi sumber daya alam dan hasilnya di Kelas IV SD Negeri 050604 Bekiun. Aktivitas guru maupun aktivitas siswa masih berkategori cukup,.Aspek yang 
masih perlu diperbaiki antara lain dari aktivitas guru adalah mengadakan apersepsi, memberikan penjelasan dengan bahasa yang sederhana, melaksanakan pembelajaran sesuai dengan urutan kegiatan pada RPP, kemampuan menggunakan model pembelajaran, penggunaan alokasi waktu sesuai rencana pelaksanaan pembelajaran, dan pada aktivitas siswa adalah mendengarkan penjelasan guru dengan baik, berpartisipasi aktif dalam proses pembelajaran, kemampuan menjawab pertanyaan dari guru, dan disiplin dalam mengikuti pembelajaran.Selanjutnya setelah dilakukan tes diperoleh bahwa hasil belajar siswa belum mencapai kriteria minimal ketuntasan klasikal 85\%, karena baru 20 orang $(74,1 \%)$ yang tuntas belajar dari 27 orang siswa.

Hasil pelaksanaan tindakan pada siklus I belum memenuhi kriteria persyaratan untuk menjawab tujuan dan persyaratan penelitian tindakan kelas yaitu pelaksanaan pembelajaran mendengarkan penjelasan guru dengan baik, (2) peneliti memberikan motivasi secara kontinu selama proses pembelajaran sehingga siswa dapat berpartisipasi aktif dalam proses pembelajaran, (3) peneliti memberikan bimbingan dan arahan kepada siswa sehingga mampu menjawab pertanyaan, dan (4) peneliti berusaha terus menerus mengingatkan tentang tata tertib selama mengikuti pembelajaran di dalam kelas sehingga siswa menjadi disiplin dalam mengikuti pembelajaran.

\section{Deskripsi Data Hasil Pelaksanaan Tindakan Siklus II}

berkategori baik dan hasil belajar siswa tuntas secara klasikal, maka penelitian dilanjutkan pada tindakan siklus II dengan memperbaiki aspek-aspek yang masih cukup dan meningkatkan aspek yang sudah baik pada siklus I.Aspek yang diperbaiki dari aktivitas guru antara lain; (1) peneliti mempelajari materi-materi yang terkait dengan materi yang akan diajarkan sehingga pada melaksanakan apersepsi dapat berjalan dengan baik, (2)peneliti berusaha menjelaskan materi pembelajaran menggunakan bahasa yang jelas dan dapat dimengerti oleh siswa, (3) peneliti berusahan melakukan pembelajaran sesuai urutan pelaksanaan yang ada pada RPP, (4) peneliti membaca kembali langkah-langkah penggunaan model pembelajaran, (5) peneliti berusaha melaksanakan pembelajaran dengan alokasi waktu sesuai yang tertulis pada rencana pelaksanaan pembelajaran, dan pada aktivitas siswa yaitu (1) peneliti berusaha memberikan arahan dan motivasi supaya siswa dapat Setelah dilaksanakan refleksi pada siklus I maka penelitian dilanjutkan ke siklus II dimana data hasil belajar yang diperoleh di kelas IV SD SD Negeri 050604 Bekiun terdiri dari hasil pelaksanaan pembelajaran dan ketuntasan hasil belajar siswa sebagai berikut:

\section{Hasil Observasi Aktivitas Guru Siklus II}

Hasil observasi aktivitas guru dapat dilihat pada Tabel 6 


\section{Tabel 6 Hasil Observasi Ativitas Guru}

\begin{tabular}{|c|c|c|}
\hline No & ASPEK YANG DIOBSERVASI & SKOR \\
\hline 1. & Ketrampilan membuka pelajaran. & 68 \\
\hline 2. & $\begin{array}{l}\text { Menyampaikan materi dan tujuan pembelajaran } \\
\text { secara sistematis }\end{array}$ & 70 \\
\hline 3. & $\begin{array}{l}\text { Memberikan penjelasan dengan bahasa yang } \\
\text { sederhana dan jelas }\end{array}$ & 68 \\
\hline 4. & Penguasaan kelas & 67 \\
\hline 5. & $\begin{array}{l}\text { Melaksanakan proses pembelajaran secara } \\
\text { sistematis dengan urutan sesuai RPP }\end{array}$ & 68 \\
\hline 6. & $\begin{array}{l}\text { Penggunaan model Snowball throwing pada } \\
\text { proses pembelajaran }\end{array}$ & 66 \\
\hline 7. & Motivasi siswa untuk aktif bertanya & 67 \\
\hline 8. & Memberikan penilaian & 67 \\
\hline 9. & $\begin{array}{l}\text { Membuat rangkuman sesuai dengan model yang } \\
\text { diterapkan }\end{array}$ & 65 \\
\hline 10. & Menutup pelajaran. & 65 \\
\hline \multicolumn{2}{|r|}{ Jumlah } & 671 \\
\hline \multicolumn{2}{|r|}{$\mathrm{HP}=\frac{\text { Jumlah Hasil Observasi }}{\text { Jumlah Butir Pengamatan }}$} & 67,1 \\
\hline & KATEGORI & Baik \\
\hline
\end{tabular}

\section{Hasil Observasi Aktivitas Siswa}

Hasil observasi aktivitas siswa pada siklus II dimana guru kelas $\mathrm{V}$ masih tetap menjadi observer untuk menilai dan mengamati aktivitas siswa selama proses pembelajaran berlangsung. Adapun hasil observasi aktivitas siswa dapat dilihat pada Tabel 7

\section{Tabel 7. Hasil Observasi untuk Aktivitas Siswa Siklus II}

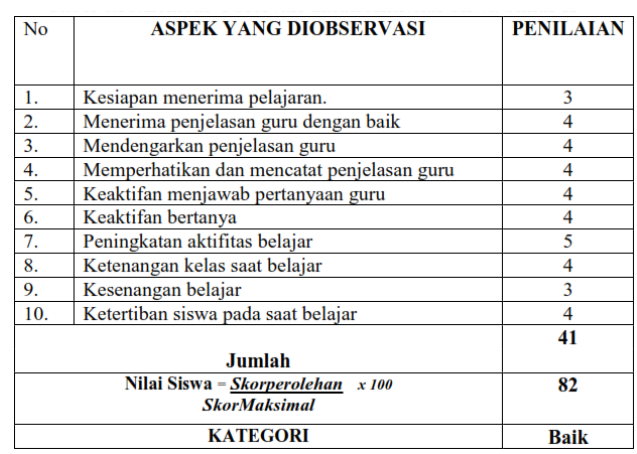

Hasil pelaksanaan pembelajaran dari aktivitas siswa diperoleh hasil sebesar 82 termasuk kategori baik.
Hasil pelaksanaan pembelajaran dari aktivitas guru dan siswa siklus II dapat disajikan dalam diagaram batang seperti pada Gambar 6 dan Gambar 7

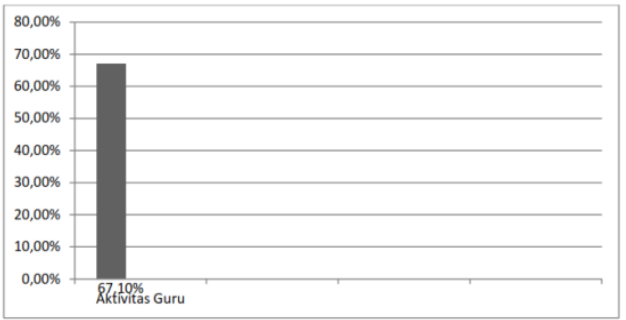

Gambar 6. Hasil observasi aktivitas guru siklus II 


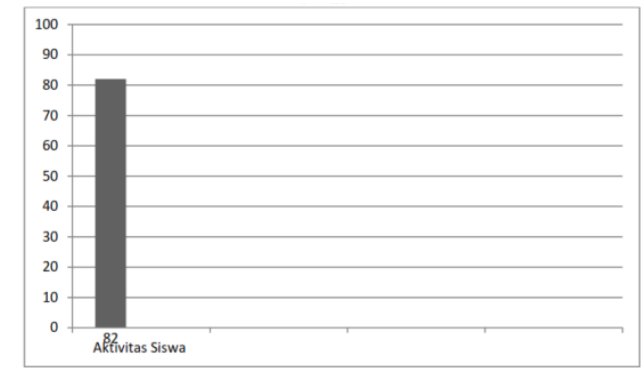

\section{Gambar 7. Hasil observasi aktivitas siswa siklus II}

\section{Ketuntasan Hasil Belajar Siswa Siklus}

II

\section{Ketuntasan Hasil Belajar Siswa \\ Secara Individu Siklus II}

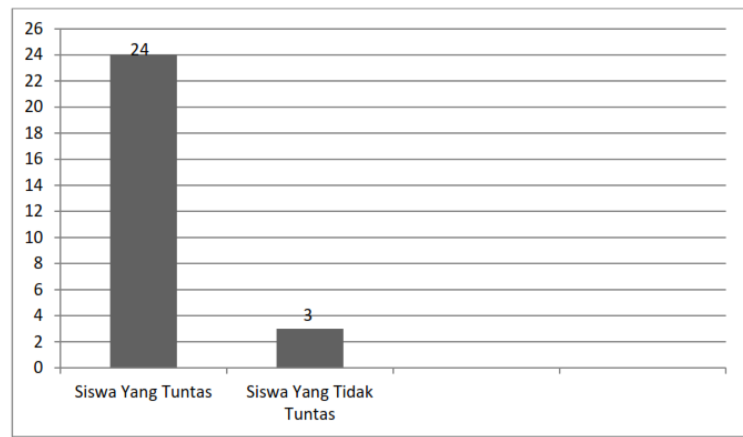

\section{Gambar 8. Diagram Ketuntasan Hasil Belajar Siswa Secara Individu Siklus II}

Dari Gambar 8, hasil belajar siswa pada siklus II secara individu meningkat. Dari 27 orang siswa, sebanyak 24 orang siswa yang tuntas secara individu dan 3 orang tidak tuntas.
Ketuntasan Hasil Belajar Siswa Secara Klasikal Siklus II

Data ketuntasan klasikal dapat disajikan dalam diagram batang seperti pada Gambar 9

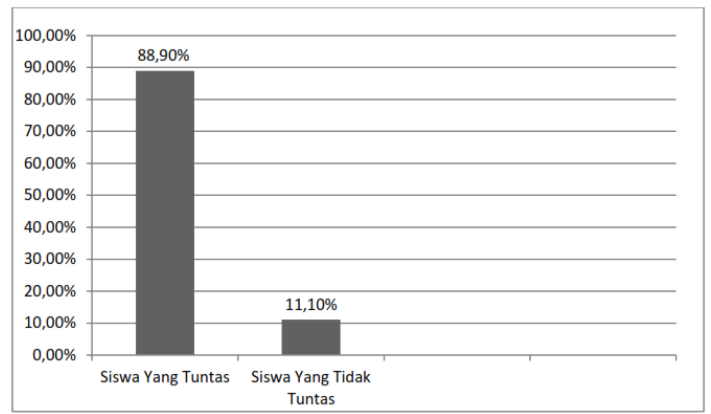

Gambar 9. Diagram Ketuntasan Hasil Belajar Siswa Secara Individu Siklus II

\section{Rata-rata Hasil Belajar Siswa}

Data ketuntasan belajar siswa secara individu di atas disajikan pada Tabel 8 
Tabel 8. Distribusi Frekuensi Rata-rata Hasil Belajar Siswa Siklus II

\begin{tabular}{|c|c|c|c|c|}
\hline No & Nilai & $f_{i}$ & $x_{i}$ & $f_{i} x_{i}$ \\
\hline 1 & $45-52$ & 1 & 48,5 & 48,5 \\
2 & $53-60$ & 2 & 56,5 & 113 \\
3 & $61-68$ & 6 & 64,5 & 387 \\
4 & $69-76$ & 9 & 72,5 & 652,5 \\
5 & $77-84$ & 5 & 80,5 & 402,5 \\
6 & $85-92$ & 4 & 88,5 & 354 \\
\hline$\Sigma$ & - & 27 & - & 1957,5 \\
\hline
\end{tabular}

Dari data nilai rata-rata siswa yang diperoleh pada Tabel 9, dapat disajikan melalui histogram pada Gambar 10

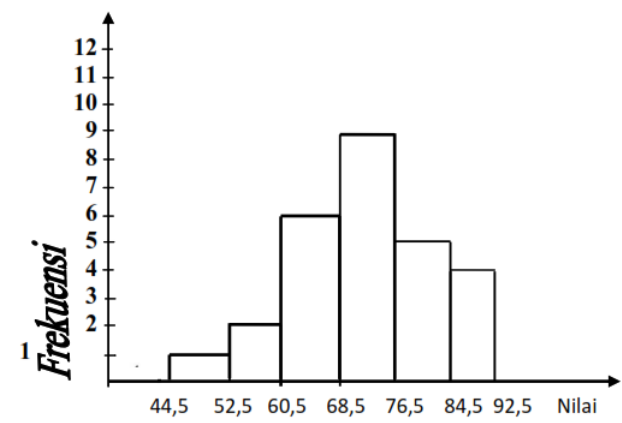

\section{Gambar 10 Histogram Data Hasil Belajar Siswa Siklus II}

\section{Refleksi Siklus II}

Dari hasil analisis data pada siklus II diperoleh bahwa pelaksanaan pembelajaran aktivitas guru dan aktivitas siswa dengan menggunakan model Snowball Throwing pada mata pelajaran IPA materi sumber daya alam dan hasilnya di Kelas IV SD Negeri 050604 Bekiun, meningkat dari kategori cukup pada siklus I menjadi kategori baik pada siklus II. Demikian juga dengan ketuntasan hasil belajar siswa sudah melebihi kriteria minimal ketuntasan klasikal 85\%, karena pada siklus II dari 27 orang siswa yang tuntas belajar 24 orang $(88,9 \%)$ dan 3 orang $(11,1 \%)$ yang belum tuntas belajar, sehingga perbaikan pembelajaran tidak dilanjutkan pada siklus III.

\section{Pembahasan Hasil Penelitian}

Dari hasil penelitian yang telah dilaksanakan di kelas IV SD Negeri 050604 Bekiun Tahun Ajaran 2016/2017 dengan jumlah siswa sebanyak 27orang dalam penerapan model Snowball throwing materi sumber daya alam dan hasilnya , dapat diperoleh:

\section{Pelaksanaan Pembelajaran Siklus I dan Siklus II}

\section{Hasil Observasi Aktivitas Guru Siklus I dan Siklus II}

Berdasarkan hasil observasi aktivitas guru pada siklus I dan Siklus II diperoleh aktivitas guru 59,8\% termasuk kategori cukup. Sedangkan hasil observasi pada siklus II diperoleh $67,1 \%$ yang termasuk kategori baik. Untuk mengetahui perubahan pelaksanaan peningkatan pelaksanaan pembelajaran aktivitas guru dari siklus I ke siklus II dapat dilihat pada Gambar 11 


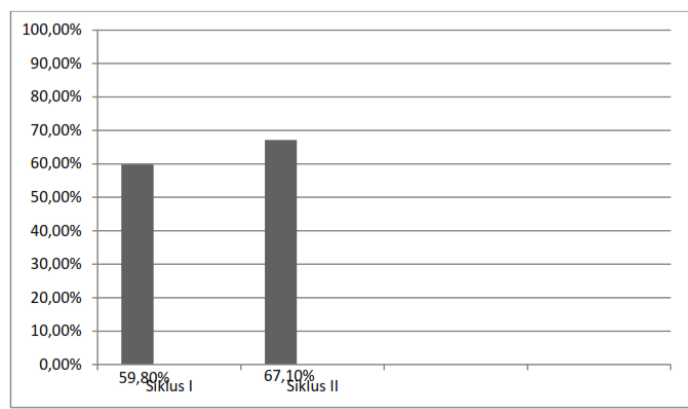

Gambar 11 Diagram hasil Observasi Aktivitas Guru Siklus I dan Siklus II

Hasil Observasi Aktivitas Siswa Siklus I dan Siklus II

Berdasarkan hasil observasi aktivitas siswa pada siklus I diperoleh nilai 68 termasuk kategori cukup. Sedangkan hasil observasi siklus II diperoleh nilai
82 termasuk kategori baik. Untuk mengetahui peningkatan pelaksanaan pembelajaran aktivitas siswa dari siklus I ke siklus II dapat dilihat pada Gambar 12

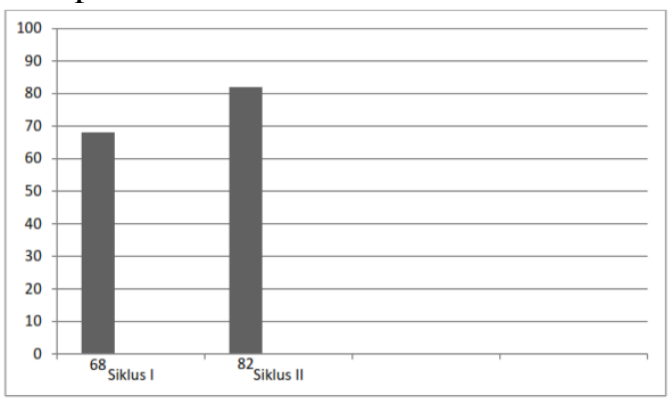

Gambar 12. Diagram hasil Observasi Aktivitas Siswa Siklus I dan Siklus II

Ketuntasan Hasil Belajar Siklus I dan

Siklus II

Rekapitulasi ketuntasan hasil belajar

Ketuntasan Belajar Siswa Secara Individu Siklus I dan Siklus II siswa secara individu dapat dilihat pada Tabel 9

Tabel 9. Rekapitulasi Hasil Belajar Siswa Siklus I dan Siklus II

\begin{tabular}{|l|c|c|c|}
\hline Siswa Tuntas & $\begin{array}{c}20 \\
(74,1 \%)\end{array}$ & $\begin{array}{c}24 \\
(88,9 \%)\end{array}$ & Meningkat \\
\hline Siswa Tidak Tuntas & $7(25,9 \%)$ & $3(11,1 \%)$ & Menurun \\
\hline Rata-rata & Siklus I & Siklus II & Meningkat \\
& 69,27 & 72,5 & \\
\hline
\end{tabular}

\section{Ketuntasan Hasil Belajar Siswa}

Secara Klasikal Siklus I dan Siklus II

Ketuntasan belajar siswa secara klasikal siklus I dan siklus II dapat dilihat pada Tabel 10 
Tabel 10. Ketuntasan Belajar Siswa Secara Klasikal Siklus I dan Siklus II

\begin{tabular}{|l|c|c|c|c|c|}
\hline \multirow{2}{*}{ Ketuntasan } & \multicolumn{2}{|c|}{ Siklus I } & \multicolumn{2}{c|}{ Siklus II } & \multirow{2}{*}{ Keterangan } \\
\cline { 2 - 5 } & $\begin{array}{l}\text { Jumlah } \\
\text { Siswa }\end{array}$ & Persentase & $\begin{array}{l}\text { Jumlah } \\
\text { Siswa }\end{array}$ & Persentase & \\
\hline $\begin{array}{l}\text { Siswa yang } \\
\text { tuntas } \\
\text { Belajar }\end{array}$ & 20 & $74,1 \%$ & 24 & $88,9 \%$ & Meningkat \\
\hline $\begin{array}{l}\text { Siswa yang } \\
\text { tidak tuntas } \\
\text { belajar }\end{array}$ & 7 & $25,9 \%$ & 3 & $11,1 \%$ & Menurun \\
\hline
\end{tabular}

Data ketuntasan hasil belajar siswa secara klasikal pada siklus I dan siklus II

batang seperti yang disajikan pada dapat digambarkan melalui Diagram

Gambar 13

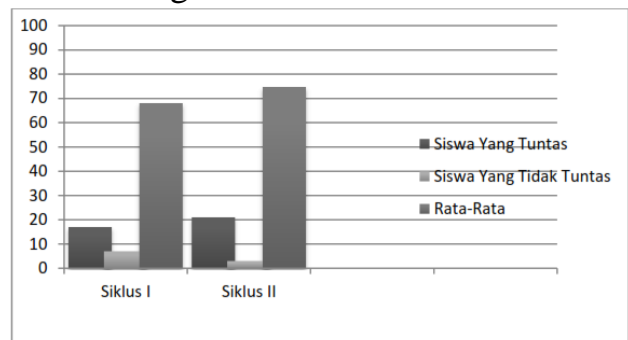

Gambar 13. Diagram Peningkatan Ketuntasan Hasil Belajar Siswa Secara Klasikal Siklus I dan Siklus II

Nilai Rata-rata siswa Siklus I dan Siklus II

Nilai rata-rata siswa siklus I dan siklus II dapat dilihat pada Tabel 11

Tabel 11 Nilai Rat-Rata Siswa Siklus I dan Siklus II

\begin{tabular}{|c|c|c|c|}
\hline Nilai & Siklus I & Siklus II & Keterangan \\
\hline Rata-rata & 69,27 & 72,5 & Meningkat \\
\hline
\end{tabular}

Data nilai rata-rata pada siklus I dan siklus II dapat digambarkan dalam grafik pada Gambar 14

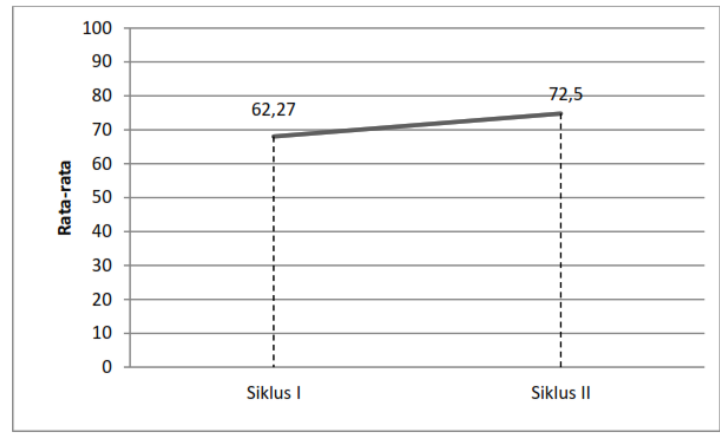

Gambar 14. Diagram Garis Peningkatan Nilai Rata-rata Hasil Belajar Siswa Siklus I dan Siklus II

Berdasarkan uraian pembahasan tersebut, maka hipotesis tindakan yang dinyatakan yaitu "Dengan menggunakan model Snowball throwing dapat 
meningkatkan hasil belajar siswa pada mata pelajaran IPA dalam materi sumber daya alam dan hasilnya pada semester II di kelas IV SD Negeri 050604 Bekiun Tahun Ajaran 2016/2017" diterima.

\section{Kesimpulan dan Saran}

Dari hasil analisis data dan pembahasan dapat disimpulkan bahwa (1) Pelaksanaan pembelajaran dengan menggunakan model Snowball Throwing pada mata pelajaran IPA materi sumber daya alam dan hasilnya di Kelas IV SD Negeri 050604 BekiunTahun Pelajaran 2016/2017 berkategori baik (2) Hasil belajar siswa meningkat setelah menggunakan model Snowball Throwing pada mata pelajaran IPA materi materi sumber daya alam dan hasilnya di Kelas IV SD Negeri 050604 BekiunTahun Pelajaran 2016/2017.

Berdasarkan penelitian yang telah dilaksanakan, penulis manyampaikan beberapa saran sebagai berikut (1) Bagi guru diharapkan dapat menggunakan model snowball throwing sebagai alternatif pada pelaksanaan pembelajaran IPA matari sumber daya alam dan hasilnya (2) Bagi peneliti selanjutnya diharapkan dapat menguasai dan menerapkan model snowball throwing saat malaksanakan pembelajaran yang agar hasilnya maksimal.

\section{DAFTAR PUSTAKA}

Arikunto,S.(2015).Penelitian Tindakan Kelas. Jakarta: Bumi Aksara

Aqib, Z. (2014). Penelitian Tindakan Kelas.Bandung:Yrama Widya
Hamalik, O. (2013). Kurikulum dan Pembelajaran. Jakarta: PT. Bumi Aksara

Huda,M.(2014).Model-Model Pengajaran Dan pembelajaran. Yogyakarta: Pustaka belajar.

Istarani. (2014). 58 Model Pembelajaran Inovatif. Medan: Media Persada.

Slameto.(2013).Belajar Dan FaktorFaktor Yang Mempengaruhi. Jakarta: Rineka Cipta.

Sagala,S. (2012).Konsep Dan Makna Pembelajaran Untuk Membantu Memecahkan problematika Belajar dan mengajar. Bandung: Alphabeta.

Sahertian,A.P.(2013).Supervisi

Pendidikan. Jakarta: Rineka Cipta.

Sanjaya,W.(2013).StrategiPembelajaran. Jakarta:Kencana PRENADA.

Shoimin, A. (2014). 68Model Pembelajaran Inovatif. Yogyakarta: AR-Ruzz Media.

Sudjana.(2012).Metode Statitiska. Bandung: Tarsito.

Susanto,A.(2013).Teori Belajar Pembelajaran. Jakarta: Kencana Prenada

Tampubolon,Saur.(2014).Penelitian Tindakan Kelas. Jakarta: Penerbit Erlangga.

Trianto.(2014).Mendesain Model Pembelajaran Inovatif-Progresif. Jakarta: Kencana Prenada 